as the cleaning of the outside of the cars." The Rock Island was proud of its Peoria Rocket, and the train did have certain things in its favor. One favorable aspect of the train was its speed. It made the run from Chicago to Peoria in 2 hours, 45 minutes, (and still does) which is faster than the airlines when downtown to airport time is considered. ${ }^{142}$ It is trains like these that should be promoted, because if they can beat the airlines, they have a chance of emerging successfully.

But even in the 60 's, Rock Island was still experimenting with fare reductions in order to increase patronage. Beginning July 1, 1961, Rock Island started honoring coach tickets in parlor cars, on an experimental basis. Because of this drop in fare, parlor car patronage went up 27 percent. ${ }^{143}$ Another fare reduction of the 60 's occurred in early 1965 when Rock Island introduced "Monday through Thursday" fares. Under this plan a 25 percent reduction was given to passengers traveling on those days. ${ }^{144}$

\title{
[To be continued]
}

\section{MRS. HAROLD AVERY DONATES LUCAS TREASURE TO DEPARTMENT OF HISTORY AND ARCHIVES}

\author{
by Linda $K$. Thomson
}

On Thursday, May 27th, Mrs. Harold Vincent Avery, of Nevada, Missouri presented to the Department of History and Archives a daguerreotype of Gov. Robert Lucas, the first Territorial Governor of Iowa. This was indeed a momentous occasion as the daguerreotype is the only known one of its kind in existence and had been given to Mrs. Avery by her grandmother, Carolyn Susan Cramer, a direct descendant of Abigail Lucas, Governor Lucas' sister. Mrs.

\footnotetext{
142"Peoria Rocket Ties two Cities," p. 4. p. 7 .

${ }^{143}$ R. E. Johnson, "To the Stockholders," R.I. Annual Report, 1962, ${ }^{144}$ Des Moines Tribune, 11 January, 1965.
} 
Avery, the former Helen Eleanor Jean Travis, had received the daguerreotype ${ }^{*}$ when she was twenty-two years of age but did not actually realize the full worth of the gift until one day, in 1969, when she was revisiting the Department of History, here in Des Moines. At this time, Mrs. Avery was admiring the portrait of Governor Lucas painted in the 1870 's by Mary Fouche Murray. Mrs. Avery had been told by her grandmother that this particular portrait had been painted from the daguerreotype which was in her possession, and during her visit in 1969, Mrs. Avery happened to mention this fact to Mrs. Lida Greene, our Historical Librarian. Mrs. Greene was both surprised and delighted with the discovery for not only the Murray portrait, but also the George Henry Yewell portrait of Lucas, which resides in the Centennial Building in Iowa City, were painted from prints of this daguerreotype and no one had ever been able to discover what ever became of the original model from which the two portraits had been made.

Mrs. Avery recalled to her interested audience at the time of the presentation that her grandmother had always been "so very proud that she was a descendant of Governor Lucas". When Mrs. Avery was twelve years of age, her grandmother brought her all of the way from Marshalltown to the Department of History to view the Murray portrait of Lucas and tell of its connection to the daguerreotype.

The daguerreotype itself was made in 1852 when Lucas was seventy-one years of age. He died one year later in 1853. Mrs. Avery stated that originally five prints were to have been made but Lucas changed his mind and had only four reproduced because of the cost $-\$ 5.00$ per print.

With the discovery that the daguerreotype was invaluable, Mrs. Avery generously offered it to the Department of History to be preserved for posterity. She felt that this was its rightful place because of its connection to the Murray portrait.

"A "daguerrotype" is an early variety of photograph (first generally used in 1839), produced on a silver plate, or a copper plate covered with silver. The plate was rendered sensitive by the action of iodine, or idodine and bromine, and, after exposure in the camera, the latent image developed by the vapor of mercury. 


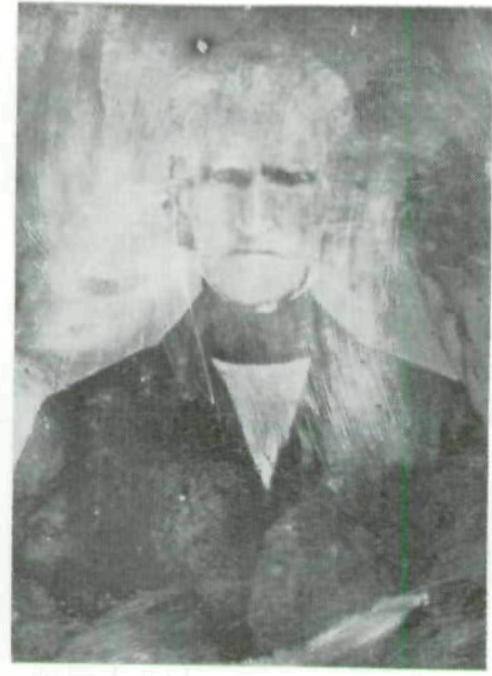

Photo of Lucas Daguerreotype before restoration.

Another interesting facet to this story is Mrs. Avery's endeavors to have the daguerreotype restored. After Mrs. Avery offered her treasure to the Department of History, she then, on her own, sought out a professional photographer who could restore the almost totally indistinguishable image of Robert Lucas on the daguerreotype. As the corresponding print will exemplify, the daguerreotype was marred, finger smudged, and scratched before Mrs. Avery had it restored. Her first step was to write to the Library of Congress and request information on someone who might be able to reclaim daguerreotypes. The Library of Congress wrote back that they knew of no one who was qualified to do this type of work. Then Mrs. Avery took the daguerrotype to a local photographer, Mr. Pierre Weltmer, in Nevada, Mo. Mr. Weltmer told her that he wouldn't attempt to work on anything so valuable but suggested a man at the University of Kansas whom he had read about as having discovered a new process for restoring daguerreotypes. This young man's name was James L. Enyeart ${ }^{\circ}$ and a series of correspondence between Mrs. Avery and Mr. Enyeart began. Mr. Enyeart was indeed able to restore the photograph of Lucas by using chemicals to bring out the image. He did such an expert job of reclamation that the daguerreotype is now almost in as good of condition as it was originally.

Mrs. Avery had kept the daguerreotype in an old trunk and in 1938 she loaned it to the Iowa Territorial Centennial Exhibition. After the Exhibition, Mrs. Avery returned the daguerreotype to the trunk where it remained for the next

\footnotetext{
${ }^{\circ} \mathrm{Mr}$. James L. Enyeart is the Curator of Photographs at the University of Kansas Museum of Art, Lawrence, Kansas.
} 
thirty years. She noted at the time of the Exhibition that the portrait was then badly faded.

Mr. and Mrs. Avery reside in Nevada, Missouri, where Mr. Avery was Assistant to the President of Cottey College. Both of the Averys are Drake graduates; Mr. Avery graduated in 1928 and Mrs. Avery in 1930. During their college days they often visited the Department of History to view the Lucas portrait.

The daguerrotype, which is housed in its original case, will be carefully wrapped and stored in a vault here in the Historical Building. Soon a qualified photographer will be contacted and copies of the daguerreotype will be made and displayed. The original daguerreotype would be damaged by continuous exposure to harsh light and for this reason, only prints of the daguerreotype will be displayed.

\section{AN EARLY SETTLER IN IOWA: WESTWARD EXPANSION IN MICROCOSM}

\section{by Dr. Bertha R. Leaman Haverford, Pennsylvania}

Dr. Leaman is a Modern European Historian with both advanced degrees from the University of Chicago and a year of study at the Sorbonne. Now retired from college and university teaching, Dr. Leaman is busily occupied with work on Franco-American relations for which she was recently awarded a grant by the American Philosophical Society.

The settlement of the State of Iowa was part of the relentless pull which produced the westward migration of the American people. Prior to 1833 there were comparatively few settlers in the State of Iowa. In 1832 the Black Hawk Purchase Treaty was signed and with it came the real beginning of the white settlements there. At an earlier date furs had lured the trapper, then the discovery of veins of lead in the hills and bluffs around Dubuque had drawn the adventurous, but it was ultimately the fine quality of the land which drew those who came to Iowa to make it their home. 
Copyright of Annals of Iowa is the property of State of Iowa, by \& through the State Historical Society of Iowa and its content may not be copied or emailed to multiple sites or posted to a listserv without the copyright holder's express written permission. However, users may print, download, or email articles for individual use. 